\title{
A Rapid and Efficient Dye Based Plate Assay Technique for Screening of L-Asparaginase Producing Fungal Strains
}

Vaishali P and Bhupendra NT*

Department of Biotechnology, Guru Ghasidas Vishwavidyalaya, India

\begin{abstract}
L-Asparaginase enzyme has received great attention owing to its potential as anticancer drug and food processing agent. L-Asparaginase producing microbes are conventionally screened on phenol red plates containing L-asparagine as the sole nitrogen source for its growth. However, the contrast of the zone in phenol red plates is not very distinct. To overcome this problem, an alternate methodology for the screening of fungal strains producing extracellular L-Asparaginase is required. In the present comparative investigation, an improved method for screening is reported, wherein Alizarin Red S and 4-Nitrophenol are implied as $\mathrm{pH}$ indicator. Plates containing Alizarin Red $\mathrm{S}$ and 4-nitrophenolare colorless at acidic $\mathrm{pH}$, turns pink and yellow respectively at alkaline $\mathrm{pH}$. Thus, a dark pink and yellow zone is formed around microbial colonies producing L-asparaginase, differentiating between enzyme producers and non-producers. Thus, we report Alizarin red $S$ and 4-Nitrophenol can detect the production of the anticancer enzyme at a much lower dye concentration which appear to be more accurate and distinctive than the conventional method for the screening of fungi producing extracellular L-Asparaginase.
\end{abstract}

Keywords: L-Asparaginase; Anticancer enzyme; Plate assay method; Alizarin Red S; 4-nitrophenol

\section{Introduction}

Along the years enzyme production has emerged as one of the most progressively growing application of microbial technology in the world market [1]. Enzymes have been used in food, beverage, textile, pharmaceutical, leather and cosmetic industries. In today's pharmaceutical market, the manufacture of enzymes as drugs is an important facet. The enzymes in the pharmaceutical industry are promoted due to its properties such as high specificity, economic production and high yield. One such enzyme that has been used for the treatment for childhood Acute Lymphoblastic Leukemia (ALL), Hodgkin's disease, Chronic Lymphocytic Leukemia, Acute Myelocytic Leukemia, Melanosarcoma is L-Asparaginase [2]. L-Asparaginase (EC 3.5.1.1) catalyzes the irreversible hydrolysis of L-asparagine into aspartic acid and ammonia under physiological conditions. L-Asparaginase has been an extensive component in the revolutionary combination chemotherapy protocols used for the treatment of childhood Acute Lymphoblastic Leukemia. In recent years, different studies aimed at finding an alternated source for the enzyme with improved characteristics such as less side effects and longer half-life as compared to L-asparaginase from $E$. coli, with economically viable production as well as causing minimal collateral effects have gained momentum. A different L-Asparaginase source, primarily fungal alternatives, has been proposed to contain less adverse effects and different features, which are advantageous for its application. L-Asparaginase has also been used in the food industry as it can degrade acrylamide found abundantly in the wide range of fried and baked food products [3]. Acrylamide has been a major concern for the health experts as it has been declared a potent neurotoxin and carcinogen $[4,5]$. Any microbial screening technique needs to be rapid, sensitive, efficient and reproducible. The enzyme had initially been screened in culture filtrates using Nessler's reagent [6,7]. This tedious and time consuming method was soon replaced by plate assay technique which has been reported to work on the principle of increase in $\mathrm{pH}$ of the medium on the production of L-Asparaginase [8]. The change in $\mathrm{pH}$ has been monitored by the incorporation of a $\mathrm{pH}$ indicator in the medium containing L-Asparagine as the sole nitrogen source. Phenol red has been used as $\mathrm{pH}$ indicator in the earlier plate based methods for the screening of extracellular L-Asparaginase producing microbes, but the method was found to be disadvantageous as the contrast between yellow and pink is indistinguishable [9]. Recently $\mathrm{pH}$ indicators such as Bromothymol blue, Methyl red and Bromocresol purple has been used for the detection of the enzyme production [1012]. In the present investigation, a rapid plate assay method utilizing Alizarin Red S and 4-nitrophenol (p- nitrophenol) for the screening of fungal isolates is reported. In addition to the plate assay, L-Asparaginase titer in the culture filtrates was also quantified.

\section{Materials and Methods}

\section{Sample collection, isolation and identification of fungal strains}

Soil samples from the sub surface were collected from different sites of the Guru Ghasidas Vishwavidyalaya, Bilaspur campus. Fungi were isolated on selective medium containing streptomycin sulphate (100 $\mu \mathrm{g} \mathrm{ml}$ ) of Potato Dextrose Agar (PDA) medium. The soil suspensions were serially diluted and plated on the above selective medium so as to inhibit bacterial growt [13]. The isolated fungal strains were stained using Lactophenol cotton blue and identified taxonomically based on their morphological characters [14].

\section{Screening of L-Asparaginase producing fungal strains}

For the screening of L-Asparaginase producing fungal strains modified Czapek-Dox agar medium containing $\left(\mathrm{g} \mathrm{L}^{-1}\right): 2 \mathrm{~g}$ glucose; 10 g L-asparagine; $1.52 \mathrm{~g} \mathrm{KH}_{2} \mathrm{PO}_{4} ; 0.52 \mathrm{~g} \mathrm{MgSO}_{4} \cdot 7 \mathrm{H}_{2} \mathrm{O} ; 0.52 \mathrm{~g} \mathrm{KCl} ; 20 \mathrm{~g}$

*Corresponding author: Bhupendra NT, Department of Biotechnology, Guru Ghasidas Vishwavidyalaya, India; Tel: 91-9406034535, 91-8109613223; Fax: 917752260148; E-mail: tiwarybn8@gmail.com

\section{Received June 09, 2017; Accepted July 12, 2017; Published July 19, 2017}

Citation: Vaishali P, Bhupendra NT (2017) A Rapid and Efficient Dye Based Plate Assay Technique for Screening of L-Asparaginase Producing Fungal Strains. J Microb Biochem Technol 9:162-168. doi: 10.4172/1948-5948.1000361

Copyright: $\odot 2017$ Vaishali $P$, et al. This is an open-access article distributed under the terms of the Creative Commons Attribution License, which permits unrestricted use, distribution, and reproduction in any medium, provided the original author and source are credited. 
agar and trace $\mathrm{CuSO}_{4}, \mathrm{ZnSO}_{4} \cdot 7 \mathrm{H}_{2} \mathrm{O}, \mathrm{FeSO}_{4} \cdot 7 \mathrm{H}_{2} \mathrm{O}[10]$. The media was supplemented with varying concentrations $(0.000-0.009 \% \mathrm{v} / \mathrm{v})$ of Alizarin Red S dye (Hi-Media) and 4-nitrophenol (Hi-Media). Plates with dye were inoculated with test cultures and incubated at $28 \pm 2^{\circ} \mathrm{C}$ for $96 \mathrm{~h}$, whereas the plates without dye served as positive control. Similarly, the culture broth supplemented with $0.001 \%$ to $0.009 \% \mathrm{v} / \mathrm{v}$ of Alizarin Red S dye and 4-nitrophenol were inoculated with test cultures and incubated at $28 \pm 2^{\circ} \mathrm{C}$ for 24 to $96 \mathrm{~h}$ whereas broth without dye was set as control.

\section{Enzyme titer studies for the quantitative estimation of L-Asparaginase production}

The modified Czapek Dox broth was used as the production medium for quantitative estimation of $\mathrm{L}$-Asparaginase. The mycelia were harvested at an interval of $12 \mathrm{~h}$ from the culture broth by filtration using Whatman no. 1 filter paper. The culture filtrate was used as the crude enzyme source for L-Asparaginase assay. The activity of L-Asparaginase enzyme in the crude extract was determined by the estimation of liberated ammonia from the hydrolysis of L-Asparagine with slight modifications [6]. The $0.1 \mathrm{ml}$ of crude extract was added to $0.9 \mathrm{ml}$ of
$0.05 \mathrm{M}$ phosphate buffer ( $\mathrm{pH} 7.8$ ) and $0.5 \mathrm{ml}$ of $0.04 \mathrm{M} \mathrm{L}$-Asparagine and the volume was made up to $2 \mathrm{ml}$ with distilled water. The resulting suspension was incubated at $37^{\circ} \mathrm{C}$ for 30 min followed badding $0.5 \mathrm{ml}$ of $1.5 \mathrm{M}$ Trichloro acetic acid (TCA) to stop the enzymatic reaction. In the next step, $0.1 \mathrm{ml}$ of the above solution was diluted with 3.5 $\mathrm{ml}$ of distilled water and $0.4 \mathrm{ml}$ of Nessler's reagent. After $10 \mathrm{~min}$ of incubation at room temperature the absorbance was recorded at 450 nm with a UV-Spectrophotometer (Shimadzu spectrophotometer, UV1800). The standard graph of ammonium sulphate was prepared for the estimation of the sample concentration. For the blank preparation, the crude extract was added after TCA. Enzyme activity was expressed in international units (IU) $\mathrm{ml}^{-1}$, which is defined as the amount of enzyme that catalyzes the formation of $1 \mu \mathrm{mol}$ of $\mathrm{NH} 3 \mathrm{~min}^{-1}$.

\section{Results}

\section{Isolation and identification of fungal isolates}

A total of 50 fungal strains were isolated from the soil samples using serial dilution method by incubating the plates of PDA at $30 \pm$ $2^{\circ} \mathrm{C}$ for $96 \mathrm{~h}$, of which Aspergillus spp., Fusarium spp. and Penicillium

\begin{tabular}{|c|c|c|c|}
\hline S. No. & Isolate Name & Microscopic Morphological characters & Taxonomic Classificatior \\
\hline 1 & BV-A & \multirow{26}{*}{$\begin{array}{c}\text { Hyphae: Septate } \\
\text { Conidiophore: unbranched } \\
\text { Philaides: Flask shaped covering the vesicles } \\
\text { Conidia: Round }\end{array}$} & \multirow{26}{*}{$\begin{array}{l}\text { Kingdom: Fungi } \\
\text { Phylum: Ascomycota } \\
\text { Class: Eurotiomycetes } \\
\text { Order: Eurotiales } \\
\text { Family: Trichocomaceae } \\
\text { Genus: Aspergillus spp. }\end{array}$} \\
\hline 2 & BV-B & & \\
\hline 3 & BV-C & & \\
\hline 4 & BV-D & & \\
\hline 5 & $B V-E$ & & \\
\hline 6 & BV-F & & \\
\hline 7 & $B V-G$ & & \\
\hline 8 & BV-H & & \\
\hline 9 & BV-I & & \\
\hline 10 & BV-J & & \\
\hline 11 & BV-K & & \\
\hline 12 & $B V-L$ & & \\
\hline 13 & BV-M & & \\
\hline 14 & BV-N & & \\
\hline 15 & BV-O & & \\
\hline 16 & BV-P & & \\
\hline 17 & $B V-Q$ & & \\
\hline 18 & BV-R & & \\
\hline 19 & BV-S & & \\
\hline 20 & $B V-T$ & & \\
\hline 21 & BV-U & & \\
\hline 22 & BV-V & & \\
\hline 23 & BV-W & & \\
\hline 24 & BV-X & & \\
\hline 25 & $B V-Y$ & & \\
\hline 26 & BV - Z & & \\
\hline 27 & BV-A1 & \multirow{10}{*}{$\begin{array}{l}\text { Appearance of thecolonies: Wooly } \\
\text { Septa: Smaller and fewer } \\
\text { Microconidia: Present in chains or beads } \\
\text { Spores: Multishaped }\end{array}$} & \multirow{10}{*}{$\begin{array}{l}\text { Kingdom: Fungi } \\
\text { Phylum: Ascomycota } \\
\text { Class: Sordariomycetes } \\
\text { Order: Hypocreales } \\
\text { Family: Nectriaceae } \\
\text { Genus: Fusarium spp. }\end{array}$} \\
\hline 28 & BV-B1 & & \\
\hline 29 & BV-C1 & & \\
\hline 30 & BV-D1 & & \\
\hline 31 & BV-E1 & & \\
\hline 32 & BV-F1 & & \\
\hline 33 & $\mathrm{BV}-\mathrm{G} 1$ & & \\
\hline 34 & $\mathrm{BV}-\mathrm{H} 1$ & & \\
\hline 35 & BV-I1 & & \\
\hline 36 & $B V-J 1$ & & \\
\hline
\end{tabular}




\begin{tabular}{|c|c|c|c|}
\hline 37 & BV-K1 & \multirow{14}{*}{$\begin{array}{c}\text { Mycelium: Highly branched multinucleate } \\
\text { Septa: Small } \\
\text { Hyphae: Colorless } \\
\text { Conidiophores: Branched } \\
\text { Conidiospores: Individually constricted }\end{array}$} & \multirow{14}{*}{$\begin{array}{l}\text { Kingdom: Fungi } \\
\text { Phylum: Ascomycota } \\
\text { Class: Eurotiomycetes } \\
\text { Order: Eurotiales } \\
\text { Family: Trichocomaceae } \\
\text { Genus: Penicillium spp. }\end{array}$} \\
\hline 38 & BV-L1 & & \\
\hline 39 & BV-M1 & & \\
\hline 40 & BV-N1 & & \\
\hline 41 & BV-01 & & \\
\hline 42 & BV-P1 & & \\
\hline 43 & BV-Q1 & & \\
\hline 44 & BV-R1 & & \\
\hline 45 & BV-S1 & & \\
\hline 46 & BV-T1 & & \\
\hline 47 & BV-U1 & & \\
\hline 48 & BV-V1 & & \\
\hline 49 & BV-W1 & & \\
\hline 50 & $\mathrm{BV}-\mathrm{X} 1$ & & \\
\hline
\end{tabular}

Table 1: Morphological identification of fungal isolates (Alexopolous et al. [14]).

spp. were 26, 10 and 14, respectively (Table 1). The morphological characterization of the fungal isolates was done by Lactophenol cotton blue staining and the morphological characters were recorded leading to the identification up to genus level using taxonomic key [14].

\section{Screening of L-Asparaginase producing fungal strains}

All the isolated strains were screened for the production of L-Asparaginase enzyme on modified Czapek Dox agar medium with the optimized dye concentration. Altogether 20 strains out of 50 selected showed positive results for the production of L-Asparaginase enzyme (Table 2). The change in $\mathrm{pH}$ of the production medium from 5.0 to 8.5 due to the hydrolysis of L-Asparagine to Aspartic acid and ammonia was indicated through a visible colour change in the course of experiment. The media was colourless at acidic $\mathrm{pH}$ and turned dark pink and dark yellow at alkaline $\mathrm{pH}$ after the incorporation of Alizarin Red S and 4-Nitrophenol, respectively, thus forming a dark collared zone around the fungal colonies producing L-Asparaginase, whereas, no colour change was observed around the fungal colonies lacking $\mathrm{L}$-Asparaginase in the control plates. The filtrates of the culture broths not supplemented with the two potential dyes also showed a change in $\mathrm{pH}$ from 5.0 to 8.5. The result suggested that the dyes do not affect the growth of the fungal isolates and the enzyme production.

\section{Comparative effect of optimized dye concentrations on the screening of L-Asparaginase producing fungal strains}

The present study was carried out with the objective to improve the plate assay method for the screening of fungus producing extracellular L- Asparaginase using 4-nitrophenol and Alizarin Red S as potential screening dyes. For this purpose, the fungal isolate Aspergillus spp. (BV-C) showing maximum colour contrast was selected. The change in color is attributed to the release of ammonia which increases the $\mathrm{pH}$ during the hydrolysis of L-Asparagine [15]. Studies with different concentrations of the dyes revealed that the enzyme production was directly proportional to the change in colour intensity. However, Alizarin Red S has the advantage of the development of sharp colour contrast between the unhydrolyzed and hydrolyzed L-Asparagine at a much lower concentration of $0.001 \%$ (Table 2). Also, the colour change in case of Alizarin Red S from colourless to dark pink was found to be distinctive as compared to colourless to dark yellow for 4-nitrophenol. It was also observed that the dye did not affect the growth of test fungus which was measured in terms of enzyme activity and dry weight of the fungal biomass. It was also observed that the enzyme titter studies in presence and absence of dye as the fungal biomass and $\mathrm{pH}$ of the culture remained the same.

\section{Enzyme titer studies for the quantitative estimation of L-Asparaginase production}

The culture filtrates of fungi grown in modified Czapek Dox broth were used as enzyme source and L-Asparagine served as the substrate. Enzyme activities were determined by direct nesslerization of $\mathrm{NH} 3$ and were expressed as international units (IU) $\mathrm{ml}^{-1}$ [16]. After $96 \mathrm{~h}$ of incubation, the release of ammonia was indicated by the increase in the $\mathrm{pH}$ of the culture medium. The formation of sharp and intense colour contrast suggested the production of L-asparaginase as compared with the relatively less contrasting zone formed by 4 -nitrophenol. The enzyme titter experiments clearly differentiates the course of L-Asparaginase on the basis of colour change at an optimized dye concentration of 0.001 (Figures 1, 2a and 2b) and $0.003 \%$ (Figures 3a and $3 \mathrm{~b}$ ) for both the dyes over the period of $96 \mathrm{~h}$.

\section{Discussion}

The present investigation was carried out to improve the plate assay method used for the screening of fungal strains using a more sensitive dye instead of phenol red or Bromothymol blue in L-asparaginecontaining medium. 50 fungal strains were isolated on a streptomycin containing PDA selective medium which were microscopically identified using taxonomic key $[9,10,14]$. These strains were further screened on Modified Czapek Dox medium containing Alizarin Red S and 4-Nitrophenol for the production of L-Asparaginase. The objective of incorporating a dye is to detect a change in the color of the medium due to release of ammonia after the hydrolysis of L-Asparagine to L-Aspartic acid. The previously reported dyes such as Phenol red Bromothymol blue, methyl red and Bromocresol purple were used at higher concentrations viz., $0.009 \%, 0.007 \%, 0.008 \%$ and $0.005 \%$, respectively [9-12]. However, Alizarin red $S$ and 4-nitrophenol show optimum intensity in colour change at a much lower dye concentration of $0.001 \%$ and $0.005 \%$, respectively (Table 3 ). The zone diameter of colour change in the plate assay was found to be directly proportional to the enzyme activity in quantitative assay for few fungal isolates as the control plates having no indicator also showed prominent colony formation but no zone formation. The study of fungal biomass along with L-Asparaginase in the absence of dye confirmed that the dyes did not affect the growth of the fungus proving it to be a safe alternative to the present dyes (Supplementary table). 
Citation: Vaishali P, Bhupendra NT (2017) A Rapid and Efficient Dye Based Plate Assay Technique for Screening of L-Asparaginase Producing Fungal Strains. J Microb Biochem Technol 9:162-168. doi: 10.4172/1948-5948.1000361

\begin{tabular}{|c|c|c|c|}
\hline S. No. & Isolate Name & L-Asparaginase production & Genus \\
\hline 1 & BV-C & ++++ & \multirow{26}{*}{ Aspergillus spp. } \\
\hline 2 & $\mathrm{BV}-\mathrm{K}$ & +++ & \\
\hline 3 & BV-M & +++ & \\
\hline 4 & $\mathrm{BV}-\mathrm{N}$ & +++ & \\
\hline 5 & $B V-Q$ & +++ & \\
\hline 6 & BV-R & +++ & \\
\hline 7 & BV-S & +++ & \\
\hline 8 & $B V-U$ & +++ & \\
\hline 9 & $\mathrm{BV}-\mathrm{X}$ & +++ & \\
\hline 10 & $B V-Z$ & +++ & \\
\hline 11 & BV-B & ++ & \\
\hline 12 & BV-D & ++ & \\
\hline 13 & BV-E & ++ & \\
\hline 14 & $\mathrm{BV}-\mathrm{F}$ & ++ & \\
\hline 15 & $B V-G$ & ++ & \\
\hline 16 & $\mathrm{BV}-\mathrm{H}$ & ++ & \\
\hline 17 & BV-P & ++ & \\
\hline 18 & $\mathrm{BV}-\mathrm{T}$ & ++ & \\
\hline 19 & $B V-V$ & ++ & \\
\hline 20 & $B V-Y$ & ++ & \\
\hline 21 & $B V-A$ & + & \\
\hline 22 & BV-I & + & \\
\hline 23 & $B V-J$ & + & \\
\hline 24 & $B V-L$ & + & \\
\hline 25 & BV-O & + & \\
\hline 26 & $B V-W$ & + & \\
\hline 27 & BV-A1 & +++ & \multirow{10}{*}{ Fusarium spp. } \\
\hline 28 & $\mathrm{BV}-\mathrm{C} 1$ & +++ & \\
\hline 29 & BV-E1 & +++ & \\
\hline 30 & BV-F1 & +++ & \\
\hline 31 & $\mathrm{BV}-\mathrm{H} 1$ & +++ & \\
\hline 32 & BV-I1 & +++ & \\
\hline 33 & BV-J 1 & +++ & \\
\hline 34 & BV-B1 & ++ & \\
\hline 35 & BV-D1 & ++ & \\
\hline 36 & $\mathrm{BV}-\mathrm{G} 1$ & ++ & \\
\hline 37 & $\mathrm{BV}-\mathrm{K} 1$ & +++ & \multirow{14}{*}{ Penicillium spp. } \\
\hline 38 & BV-T1 & +++ & \\
\hline 39 & BV-U1 & +++ & \\
\hline 40 & $\mathrm{BV}-\mathrm{X} 1$ & +++ & \\
\hline 41 & BV-L1 & ++ & \\
\hline 42 & $\mathrm{BV}-\mathrm{M} 1$ & ++ & \\
\hline 43 & $\mathrm{BV}-\mathrm{N} 1$ & ++ & \\
\hline 44 & BV-Q1 & ++ & \\
\hline 45 & BV-S1 & ++ & \\
\hline 46 & BV-V1 & ++ & \\
\hline 47 & BV-W1 & ++ & \\
\hline 48 & BV-O1 & + & \\
\hline 49 & BV-P1 & + & \\
\hline 50 & BV-R1 & + & \\
\hline
\end{tabular}

Table 2: Fungal isolates and their respective L-Asparaginase production potential (++++ - high production of L-Asparaginase; + - lowest production of L-Asparaginase). 


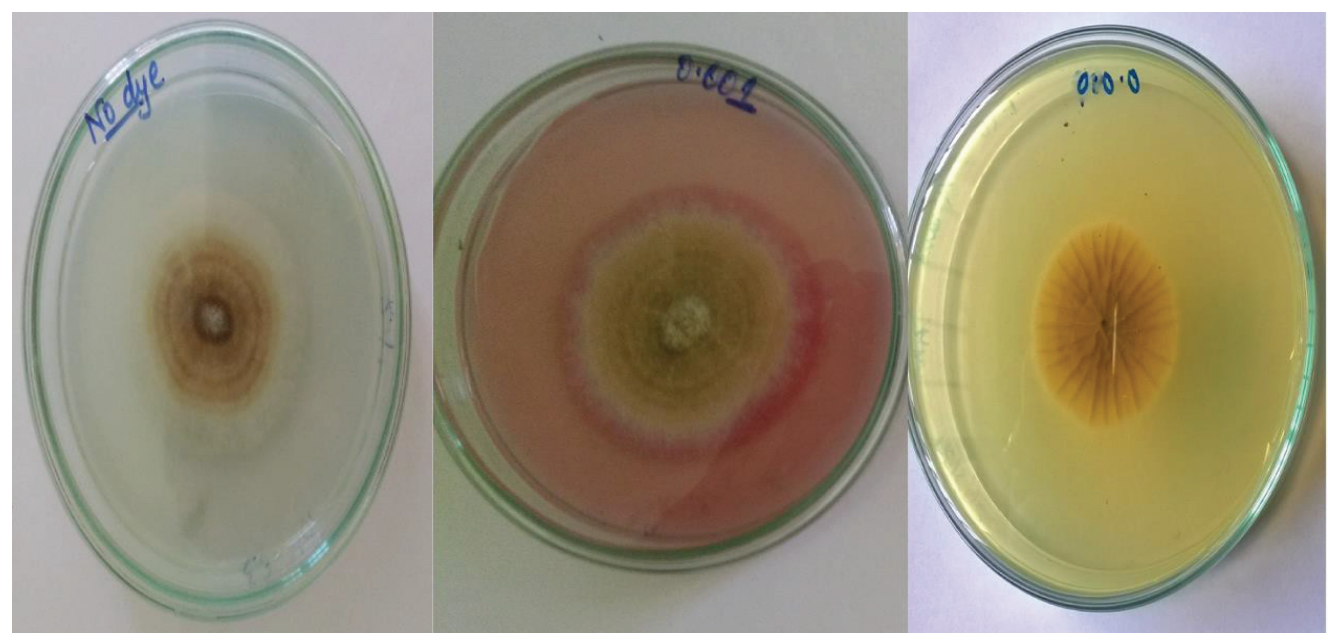

Figure 1: Plates incorporated with no dye, supplemented with Alizarin Red S and 4-Nitrophenol (Left to right).

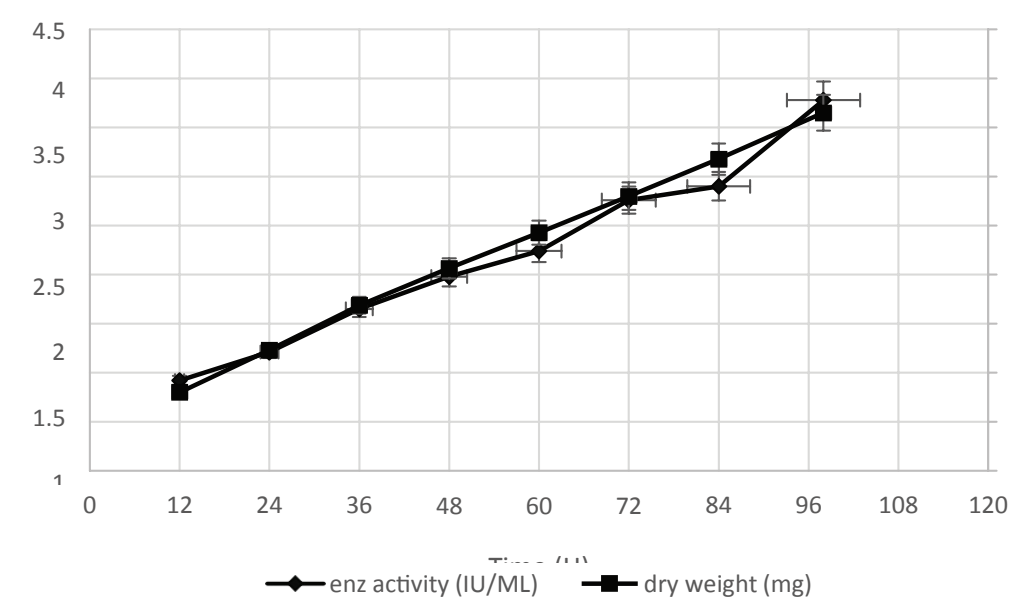

Figure 2a: Profile of enzyme production and growth in terms of dry weight $(\mathrm{mg})$ by the fungal culture in presence $0.001 \%$ of Alizarin Red S dye for Aspergillus spp. $(\mathrm{BV}-\mathrm{C})$.

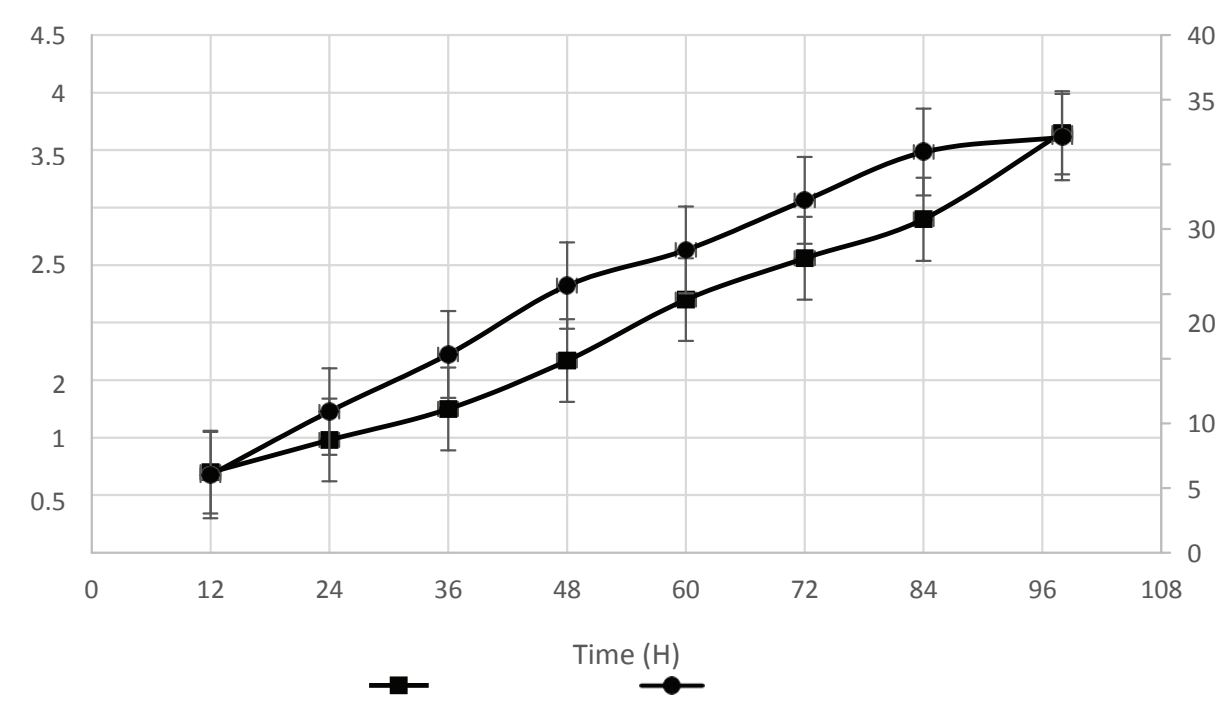

Figure 2b: Profile of enzyme production and growth in terms of dry weight $(\mathrm{mg})$ by the Aspergillus sp. culture $(\mathrm{BV}-\mathrm{C})$ in absence of dye. 


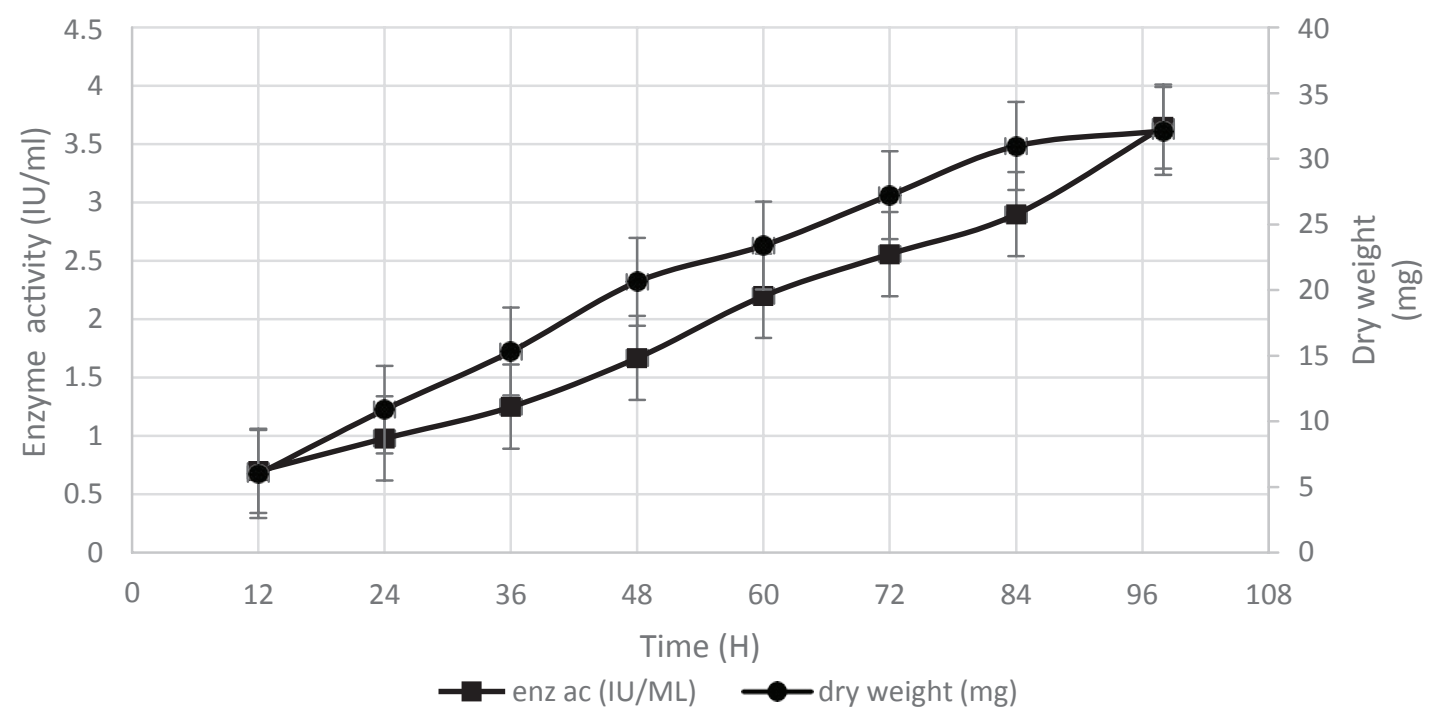

Figure 3a: Profile of enzyme production and growth in terms of dry weight ( $\mathrm{mg}$ ) by the Aspergillus sp. culture (BV-C) in presence $0.007 \%$ of 4 -nitrophenol.

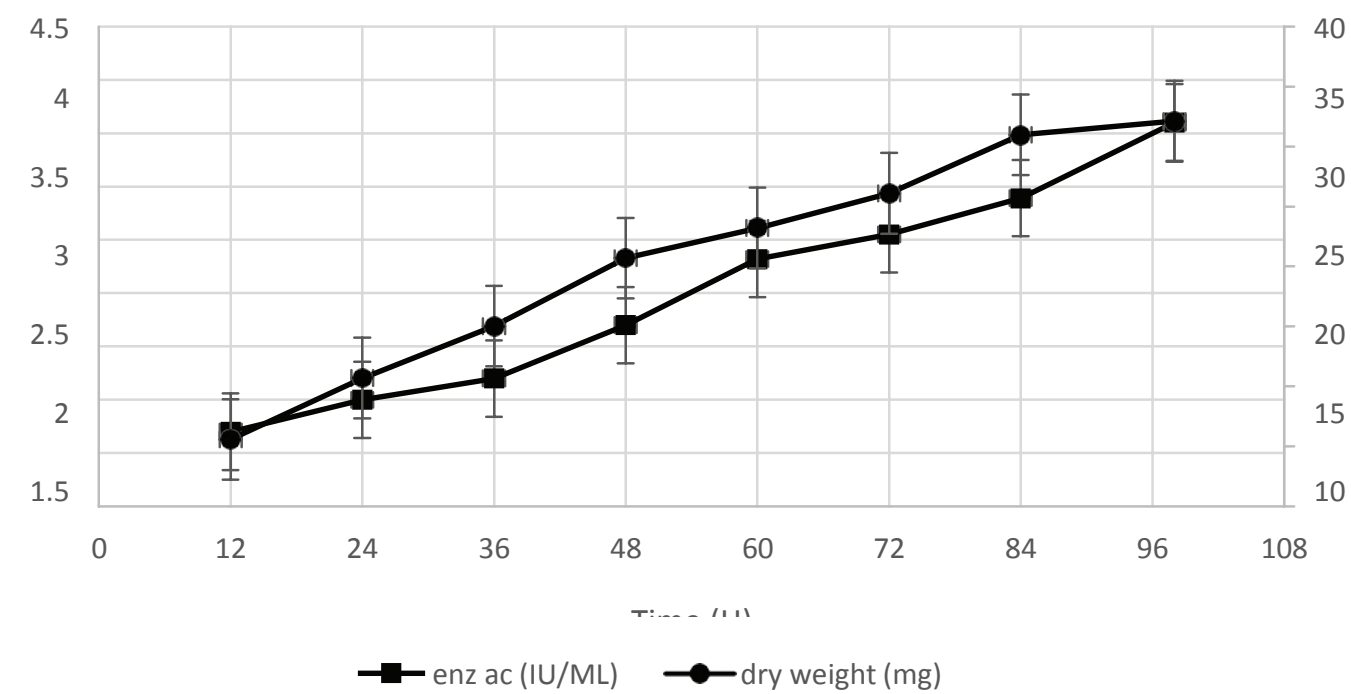

Figure 3b: Profile of enzyme production and growth in terms of dry weight (mg) by the Aspergillus sp. culture (BV-C) in absence of dye.

\begin{tabular}{|c|c|c|c|c|}
\hline \multirow[t]{2}{*}{ Concentration of dyes $(\% \mathrm{v} / \mathrm{v})$} & \multicolumn{2}{|c|}{ Alizarin Red S } & \multicolumn{2}{|c|}{ 4-nitrophenol } \\
\hline & Colony diameter $(\mathrm{cm}) \pm \mathrm{S} . \mathrm{E}^{*}$ & Zone diameter $(\mathrm{cm}) \pm \mathrm{S} . \mathrm{E}$ & Colony diameter $(\mathrm{cm}) \pm$ S.E & Zone diameter $(\mathrm{cm}) \pm \mathrm{S} . \mathrm{E}$ \\
\hline Control & $4.5 \pm 1.21$ & Nil & $3.0 \pm 1.32$ & Nil \\
\hline 0.001 & $4.5 \pm 1.04$ & $9.00 \pm 2.12$ & $4.6 \pm 1.23$ & $9.00 \pm 0.98$ \\
\hline 0.003 & $4.6 \pm 0.09$ & $9.00 \pm 0.10$ & $5.2 \pm 0.08$ & $9.00 \pm 0.07$ \\
\hline 0.005 & $4.7 \pm 0.34$ & $9.00 \pm 0.23$ & $6.3 \pm 0.05$ & $9.00 \pm 0.14$ \\
\hline 0.007 & $4.7 \pm 0.49$ & $9.00 \pm 1.09$ & $7.6 \pm 0.95$ & $9.00 \pm 0.34$ \\
\hline 0.009 & $4.8 \pm 0.04$ & $9.00 \pm 1.32$ & $7.6 \pm 0.04$ & $9.00 \pm 0.45$ \\
\hline
\end{tabular}

*S.E: Standard error of the mean

Table 3: Effect of concentrations of Alizarin Red S and 4-nitrophenol on L-asparaginase production by a representive fungal isolate Aspergillus spp. (BV-C).

\section{Conclusion}

In the present study, Alizarin Red $\mathrm{S}$ at a lower concentration
$(0.001 \%)$ showed intense color contrast indicating the production of L-Asparaginase than 4-nitrophenol concentration (0.005\%). Moreover, Alizarin Red S and 4-Nitrophenol did not affect the enzyme production 
Citation: Vaishali P, Bhupendra NT (2017) A Rapid and Efficient Dye Based Plate Assay Technique for Screening of L-Asparaginase Producing Fungal Strains. J Microb Biochem Technol 9:162-168. doi: 10.4172/1948-5948.1000361

and growth of fungi used in the study, suggesting the non-toxic nature of the $\mathrm{pH}$ indicators. Based on the overall results with the $\mathrm{pH}$ indicator dyes Alizarin Red $S$ is proposed as a better indicator than 4-Nitrophenol in terms of sensitivity for the screening of Fungal L-Asparaginase enzyme due to the clarity of the contrasting color zones.

\section{Acknowledgement}

The authors acknowledge with thanks the financial assistance from the Department of Biotechnology, Ministry of Science and Technology, Government of India under BUILDER Project (Sanction Order No. BT/PR7020/INF/22/172/2012).

\section{References}

1. Sanchez S, Demain AL (2011) Enzymes and bioconversions of industrial pharmaceutical and biotechnological significance. Org Process Res Dev 15: 224-230

2. Wriston JC Jr, Yellin TO (1973) L-Asparaginase: A review. Adv Enzymol Relat Areas Mol Biol 39: 185-248.

3. Sreenivasulu V, Jayaveera K, Rao PM (2009) Solid-state fermentation for the production of I-asparaginase by Aspergillus sp. Res J Pharmacogn Phytochem 1: 21-25.

4. Rosen J, Hellenas KE (2002) Analysis of acrylamide in cooked foods by liquid chromatography tandem mass spectrometry. Analyst 127: 880-882.

5. Tareke E, Rydberg P, Karlsson P, Eriksson S, Tornqvist M (2002) Analysis of acrylamide, a carcinogen formed in heated foodstuffs. J Agric Food Chem 50: 4998-5006.

6. Nakahama K, Imada A, Igarasi S (1973) Formation of L-asparaginase by Fusarium species. J Gen Microbiol 75: 269-273.
7. Saxena RK, Sinha U (1981) L-asparaginase and glutaminase activities in the culture filtrates of Aspergillus nidulans. Cur Sci 50: 218-219.

8. De Jong P (1972) L-Asparaginase production by Streptomyces griseus. Appl Microbiol 23: 1163-1164.

9. Gulati R, Saxena RK, Gupta R. (1997) A rapid plate assay for screening L-Asparaginase producing micro-organisms. Lett Appl Microbiol 24: 23-26.

10. Mahajan RV, Saurabh S, Saxena RK, Srivastava AK (2013) A rapid, efficient and sensitive plate assay for detection and screening of L-Asparaginase producing microorganisms. FEMS Microbiol Lett 341: 22-26.

11. Dhale MA, Mohan-Kumari HP (2014) A comparative rapid and sensitive method to screen L-asparaginase producing fungi. J Microbiol Methods 102: 66-68.

12. Meghavarnam AK, Janakiraman S (2015) A simple and efficient dye based technique for rapid screening of fungi for L-Asparaginase production. J Exp Bio Agric Sci 3: 123-130.

13. Booth C (1971) The genus Fusarium. Kew. Commonwealth Mycological Institute: 1-278.

14. Alexopolous CJ, Mims CJ, Blackwell M (1996) Introductory Mycology (4th edition), Wiley and Sons: 180-658.

15. Mahajan RV, Saran S, Kamaeshwaran K, Kumar V, Saxena RK (2012) Efficient production of L-Asparaginase from Bacillus licheniformis with low glutaminase activity: Optimization, scale up and acrylamide degradation studies. Bioresour Technol 125: 11-16.

16. Dhale MA, Mohan-Kumari PH, Sukumaran UK, Govindaswamy V (2011) Production of Monascus purpureus pigments; influenced by amidase and acid protease activity. J Food Biochem 35: 1231-1241. 